\title{
Mycorrhizal hyphae as ecological niche for highly specialized hypersymbionts - or just soil free-riders?
}

\author{
Jan Jansa*, Petra Bukovská and Milan Gryndler \\ Department of Ecology, Institute of Microbiology, Academy of Sciences of the Czech Republic, Praha, Czech Republic
}

\section{Edited by:}

Mohammad Miransari, Sharif University of Technology, Iran

\section{Reviewed by:}

Anthony Yannarell, University of Illinois at Urbana-Champaign, USA Valérie Hocher, Institut de Recherche pour le Développement, France

\section{${ }^{*}$ Correspondence:}

Jan Jansa, Department of Ecology, Institute of Microbiology, Academy of Sciences of the Czech Republic, Vídeñská 1083, 14220 Praha 4, Czech Republic.

e-mail: jansa@biomed.cas.cz
Mycorrhizal fungi interconnect two different kinds of environments, namely the plant roots with the surrounding soil. This widespread coexistence of plants and fungi has important consequences for plant mineral nutrition, water acquisition, carbon allocation, tolerance to abiotic and biotic stresses and interplant competition. Yet some current research indicates a number of important roles to be played by hyphae-associated microbes, in addition to the hyphae themselves, in foraging for and acquisition of soil resources and in transformation of organic carbon in the soil-plant systems. We critically review the available scientific evidence for the theory that the surface of mycorrhizal hyphae in soil is colonized by highly specialized microbial communities, and that these fulfill important functions in the ecology of mycorrhizal fungal hyphae such as accessing recalcitrant forms of mineral nutrients, and production of signaling and other compounds in the vicinity of the hyphae. The validity of another hypothesis will then be addressed, namely that the specific associative microbes are rewarded with exclusive access to fungal carbon, which would qualify them as hypersymbionts (i.e., symbionts of symbiotic mycorrhizal fungi). Thereafter, we ask whether recruitment of functionally different microbial assemblages by the hyphae is required under different soil conditions (questioning what evidence is available for such an effect), and we identify knowledge gaps requiring further attention.

Keywords: mycorrhizal symbiosis, hyphae-associated microbes, soil resources, mineral nutrients, carbon, hypersymbionts, theory

\section{INTRODUCTION - MYCORRHIZAL SYMBIOSIS AND ITS HYPHAE-ASSOCIATIVE MICROBES}

The association of plant roots with fungi has a very long evolutionary history (Remy et al., 1994; Berbee and Taylor, 2007) and can have different ecological outcomes, ranging from mutualistic, i.e., beneficial to both partners, to parasitic, i.e., beneficial to one partner and detrimental to the other partner (Johnson et al., 1997; Neuhauser and Fargione, 2004; Johnson and Graham, 2013). One of the oldest documented associations of "higher"1 plants with fungi is the arbuscular mycorrhizal (AM) symbiosis (Simon et al., 1993; Redecker et al., 2000). This type of association is established between more than a half of extant vascular plant species and members of a monophyletic and ancient group of soil fungi, the Glomeromycota (Schüßler et al., 2001). It is assumed that this symbiosis was established as a response to harsh environmental conditions at the time when the primitive plants were making their way from aquatic to terrestrial environments, providing them with major benefits in terms of facilitating nutrient acquisition from the primordial soils (Simon et al., 1993; Cairney, 2000; Taylor and Krings, 2005). During the evolution, some plant groups acquired fungi from sister clades (Ascomycota, Basidiomycota) as their mycorrhizal symbionts, establishing other kinds of

\footnotetext{
${ }^{1}$ Multicellular plants, often developing vascular tissues and specialized organs such as leaves, stems, and roots. Unlike others, we also count bryophytes and liverworts to this group, in spite of the fact that they sometimes develop neither vascular tissues nor specialized organs.
}

mycorrhizal symbiosis such as ericoid, orchid, or ecto-mycorrhiza (Cairney, 2000). Some plants do establish more than one type of mycorrhizal symbiosis (e.g., arbuscular and ectomycorrhizal), whereas some few plant groups completely lost the capacity to establish any kind of mycorrhizal symbiosis (Wang and Qiu, 2006; Kariman et al., 2012).

The common feature of all types of mycorrhizal symbiosis is the fact that the fungi colonize two kinds of environment, namely the roots of the host plants (or, exceptionally, rhizoids or thalli of some bryophytes) and the surrounding soil, interconnecting these two habitats with their hyphae (Read et al., 2000; Jansa and Gryndler, 2010). This specific mode of fungal life is distinguishing the mycorrhizal fungi from root endophytes, which, although sometimes capable of spreading through or temporarily colonizing the soil, do not colonize both environments simultaneously for most of their life cycle (Faeth and Fagan, 2002; Hyde and Soytong, 2008; Jansa et al., 2011). Direct interconnection of soil with the roots through mycorrhizal fungi (Figure 1) is the basis for some of the most important functional features of the mycorrhizal symbiosis, namely the improved uptake of mineral nutrients and/or water from the soil by the host plants (Jakobsen, 1983; Jakobsen et al., 1992; Schweiger and Jakobsen, 2000; Drew et al., 2003; Augé, 2004; Allen, 2007; Martin et al., 2008). Such improvements have been frequently documented for a large number of host plants, soil and climatic conditions, mainly with respect to phosphorus, nitrogen as well as some micronutrients such as zinc and copper (Mosse, 1957; Smith and Read, 2008; Jansa et al., 2011). 


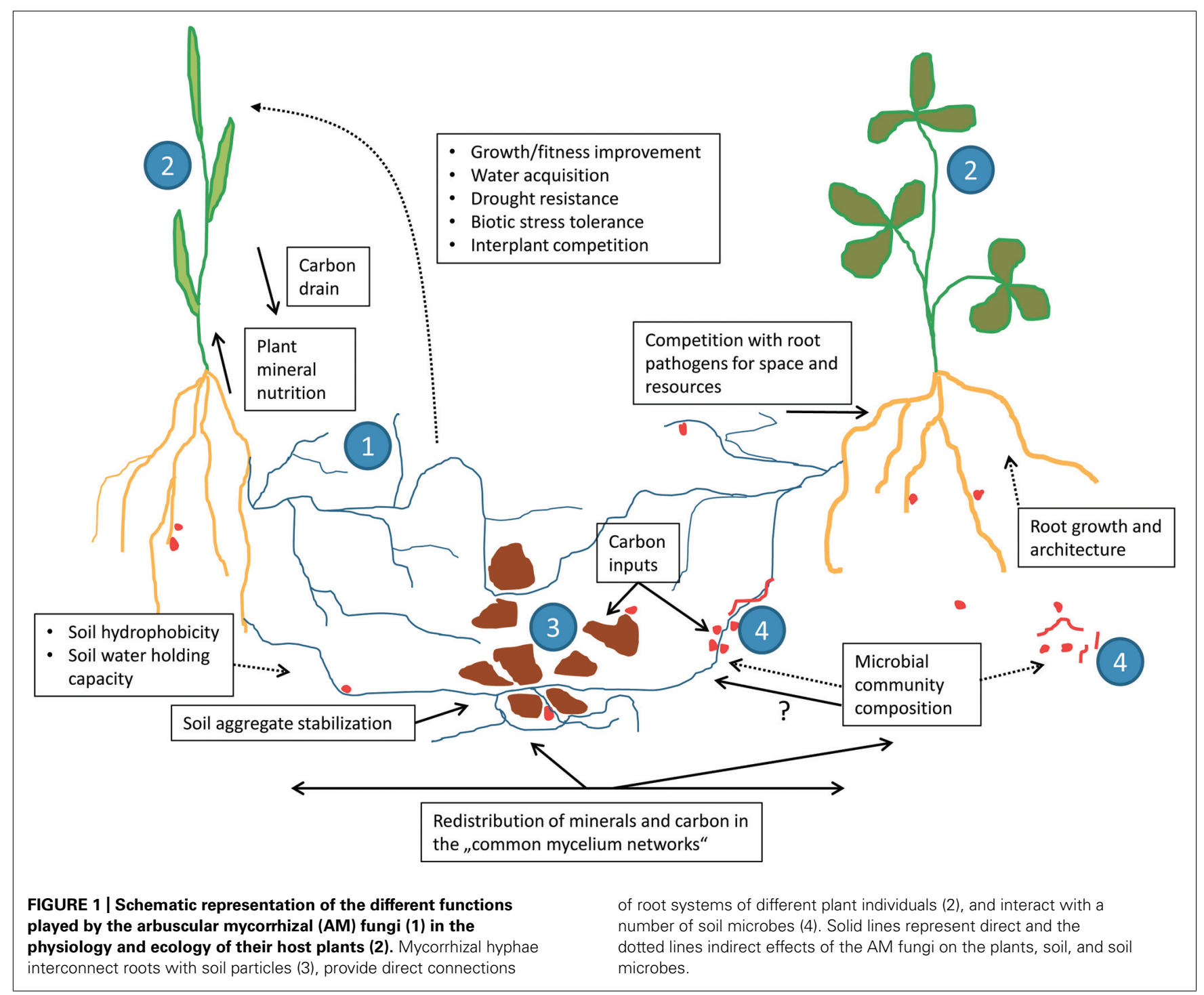

Whereas the fungal hyphae inside the roots are mainly surrounded by plant cells, presenting quite a stable and homogeneous biotic environment, the hyphae extending to the soil are exposed to a great number of various biotic interactions (Jansa and Gryndler, 2010). The hyphae are challenged by diverse communities of soil prokaryotes, fungi, protozoans, nematodes, and other organisms. The composition of communities of soil microorganisms on the surface of mycorrhizal hyphae is usually quite different from the uncolonized (bulk, non-hyphospheric) soil, depending on fungal identity and possibly quite variable throughout the hyphae lifetime (Toljander et al., 2006; Scheublin et al., 2010; Izumi et al., 2013). For example, bacteria belonging to Oxalobacteraceae were established as a group with a specific aptitude to colonize the surface of AM hyphae (Scheublin et al., 2010), whereas Burkholderia and Bradyrhizobium were present on the ectomycorrhizal hyphae associated with pine trees (Timonen and Hurek, 2006; Kataoka et al., 2008). Various pure cultures of bacteria (e.g., Rhizobium, Bacillus, Pseudomonas) showed differential levels of attachment to the AM hyphae, depending on the AM fungal species and also the vitality of the hyphae (Toljander et al., 2006). Experimental evidence also exists for hyphal exudates of AM fungi having a pronounced effect on soil bacterial community composition, with some members of Enterobacteriaceae being particularly strongly promoted (Toljander et al., 2007). Very little direct evidence exists for association of mycorrhizal hyphae with eukaryotic organisms such as yeasts, although positive interaction between AM fungi and some yeasts with respect to the levels of root colonization were reported (Botha, 2011, and references therein).

The reasons behind recruiting of a specific microflora on the mycorrhizal hyphae remain mostly unclear - whether there are specific attractants or other signals involved, or whether the development of specific hyphosphere ${ }^{2}$ microbial communities is due to the release of other compounds by the hyphae (e.g., polysaccharides), remains speculative. We know, though, that the strength of association between AM hyphae and other microbes can be quite variable (Toljander et al., 2006; Jansa and Gryndler, 2010),

${ }^{2}$ Soil volume under direct influence of AM fungal hyphae. 
ranging from loose/casual association to very tight, even intracellular mode of living (Ghignone et al., 2012). For most of the associations, the specific roles of the associative microbes in the fungal life and ecosystem processes still need to be established.

In this review we mainly focus on the AM fungi, because this is the most widespread type of mycorrhizal association. AM symbiosis has probably been the most challenging to study among all the mycorrhizal types due to the fact that the fungal partner cannot complete the life cycle without the host plant and (for most of the fungal taxa) also without the soil environment. The knowledge on this specific biological system has therefore been slower to accumulate than in other mycorrhizal types. Yet this knowledge is particularly relevant for many natural ecosystems as well as for most agricultural production systems, vegetated by plants reliant on the AM symbiosis for their nutrition and stress tolerance. Here we collate the available scientific knowledge on the identity and putative roles of AM fungal hyphae-associated microbes in relation to the mycorrhizal fungi and also to the mycorrhiza-host plants. More specifically, we analyze the potential involvement of the microbes in nutrient cycling and carbon $(\mathrm{C})$ transformation in the AM fungal hyphosphere.

\section{FUNCTIONS OF THE ASSOCIATIVE MICROBES}

Improved acquisition through the mycorrhizal host plants (as compared to the non-mycorrhizal plants) of orthophosphate and other mineral nutrients with limited diffusion in soil (e.g., $\mathrm{Zn}^{2+}$ ) has been sufficiently explained by the hyphae gathering the nutrients beyond the root depletion zone (Li et al., 1991; Jakobsen et al., 1992; Jansa et al., 2003; Schnepf and Roose, 2006; Thonar et al., 2011). However, improvements of uptake of highly mobile nutrients such as $\mathrm{N}$ in the form of nitrate or ammonium (Mäder et al., 2000; Scherer and Frost, 2004; Tanaka and Yano, 2005; Miransari, 2011; Fellbaum et al., 2012) and acquisition of nutrients bound in organic forms (Jansa et al., 2011, and references therein) have been much more difficult to explain. For example, Hodge et al. (2001) and Hodge (2003) reported increased rates of mineralization of $\mathrm{N}$ bound in plant residues in the presence of an AM fungus, and Koide and Kabir (2000) reported acquisition of $\mathrm{P}$ by the AM hyphae from organic forms in an in vitro system. This compounded previous reports on AM fungal acquisition of phosphorus from organic sources in soil (Tarafdar and Marschner, 1994; Feng et al., 2003). These findings have, however, sometimes been difficult to replicate and/or interpret (Joner and Jakobsen, 1995; Hodge et al., 2000; Hodge, 2001). Furthermore, the metabolic capacity of AM fungi to release phosphorus from organic molecules has been questioned (Joner and Jakobsen, 1995; Joner et al., 2000). Thus there are different niches where hyphaeassociative soil microbes (either prokaryotes, yeasts or filamentous fungi, alone, or together with their grazers such as collembolans, nematodes, or amoebas) could step in and play important roles in nutrient cycling and plant nutrition (Joner and Jakobsen, 1995; Leigh et al., 2011).

\section{MINERALIZATION OF ORGANIC NUTRIENTS}

Mineralization of organic nutrients seems to be primarily conducted by associative microbes such as bacteria (e.g., actinomycetes) and/or fungi, rather than the AM fungi themselves.
This is quite different from other mycorrhizal types, where the mycosymbionts recruit from fungal groups possessing effective degrading pathways for complex organic compounds (e.g., Basidiomycota) and where axenic cultures provided unequivocal proof of their degrading capacity (Bending and Read, 1997; Read et al., 2004). There is limited evidence that the AM-hyphae associative prokaryotes are responsible for the degradation of organic materials in the vicinity of the AM hyphae to extract the nutrients or energy or both, and the AM hyphae can then take the mineral nutrients released to the soil solution (Leigh et al., 2011; Herman et al., 2012). The AM fungi are thus priming the degradation of organic nutrients in soil through inducing activity of specific microbes in their hyphosphere (Talbot et al., 2008). In this respect, eukaryotic associative microbes (e.g., basidiomycetous yeasts such as Cryptococcus or Rhodotorula) are particularly interesting as these were previously shown (1) to be closely associated with AM spores and hyphae, (2) they enhance the development of mycorrhizal structures in host plant roots, and (3) they also possess specific enzymatic activities enabling degradation of complex organic molecules (Alonso et al., 2008; Boby et al., 2008; Botha, 2011). Depending on the requirements of the hyphae-associative microbes (they may need either the nutrients or the carbon, or both) these nutrients can be regarded as the desired product or a waste. In any case, AM hyphae can take up these nutrients when released to the soil solution, either directly competing with the degraders or using the surplus of the nutrients released by the associative microbes during their search for energy.

\section{PRODUCTION OF BIOACTIVE COMPOUNDS}

Some of the microbes on hyphal surface can also be involved in production of signaling, antibiotic and/or allelopathic compounds. There are relatively few details known on producers of such bioactive compounds on the surface of AM hyphae, especially because most of the microbes have not yet been cultured and their community composition is just becoming uncovered (Scheublin et al., 2010). In spite of this lack of information, there is circumstantial evidence that many of the microbes present in the AM fungal hyphosphere are producing bioactive compounds (Hoffman and Arnold, 2010; Bidondo et al., 2011; Seipke et al., 2012). For example, the presence of living microbes usually had much stronger effect on the growth of AM hyphae out of root sections under axenic conditions than many of the tested pure compounds with known signaling function, such as plant growth regulators (Gryndler et al., 1998) or flavonoids (Gryndler and Hršelová, 1998). Furthermore, there are microorganisms identified as "mycorrhiza helper bacteria" that, upon co-inoculation with the AM fungi, increase the colonization rates of the host roots (Garbaye, 1994; Frey-Klett et al., 2007; Bonfante and Anca, 2009). Production of bioactive compounds by hyphae-associated microbes could also explain some of the effects of plant-plant interactions as the hyphal networks have been shown to transfer the allelopathics over large distances in soil (Barto et al., 2011).

\section{PRODUCTION OF RECALCITRANT ORGANIC (GLOMALIN-LIKE) COMPOUNDS}

Some years ago, the AM fungi were assumed to produce an elusive recalcitrant glycoprotein called glomalin, which was predicted to 
serve as a glue sticking soil particles in aggregates, holding soil water back, and potentially increasing bioavailability of mineral nutrients, among other functions (Wright et al., 2000; Millner and Wright, 2002; Rillig, 2004; Treseder and Turner, 2007). It seems, however, that glomalin is in fact a whole group of organic compounds of unclear biological origin, some of which may well originate from the AM fungi, but then it is chewed and transformed by a number of other organisms in the soil (Gadkar and Rillig, 2006; Whiffen et al., 2007; Janos et al., 2008; Sousa et al., 2012). It is quite likely that microbes on hyphal surfaces contribute greatly to the transformations of these compounds (Bolliger et al., 2008; Gonzalez-Chavez et al., 2008), although the exact pathways and reaction rates are still unknown.

\section{TRANSFORMATION OF RECALCITRANT ORGANIC COMPOUNDS}

Along similar lines, AM hyphae-associated microbes are also likely, one way or another, to participate in oxidative polymerization of humic compounds (Piccolo et al., 2000). This process in soil is facilitated by a number of microbes producing oxidizing enzymes (Chefetz et al., 1998; Sinsabaugh, 2010; Zavarzina, 2010), and is usually wrapped under the term "humification." Not well defined due to a variety of organic compounds involved, humification is ecologically an extremely important process of long-term stabilization of soil organic matter. Although the AM-induced humification is unlikely to fully revert the catabolic processes leading to release of mineral nutrients and energy bound in the soil organic matter (Laheurte etal., 1990; Cheng etal., 2012), it is definitely a subject worth further attention, not only from carbon sequestration point of view, but also in the light of potential industrial applications (Jeon et al., 2012).

\section{ATMOSPHERIC DINITROGEN FIXATION}

Atmospheric dinitrogen fixation is an ecologically important function fulfilled solely by prokaryotes. Although there is little information on increased incidence of diazotrophic bacteria on the surfaces of AM fungi, there are studies showing that hyphae of some other (e.g., ectomycorrhizal) fungi do host such bacteria and that this may be important for nitrogen nutrition of the mycorrhizal plants such as pines (Paul et al., 2007) and/or for ripening of truffle fruitbodies (Gryndler et al., 2013, and references therein).

\section{CARBON ALLOCATION TO THE ASSOCIATIVE MICROBES}

Nearly all organic carbon ${ }^{3}$ in the soil originates from the photosynthesis carried out either by plants or by photosynthetic prokaryotes, one way or the other. The carbon fixed by the plants is first distributed throughout the plant body and a significant portion, between 4 and $30 \%$ of the net photosynthesis production, is transferred to the AM symbionts (Paul and Kucey, 1981; Jakobsen and Rosendahl, 1990; Drigo et al., 2010; Lendenmann et al., 2011; Calderon et al., 2012). This movement from the plant to the fungus is usually quite fast, taking just a few hours (Johnson et al.,

\footnotetext{
${ }^{3} \mathrm{~A}$ small fraction of the carbon in the soil organic matter can originate from nonphotosynthetic fixation of $\mathrm{CO}_{2}$ in specific metabolic pathways (e.g., Krebs cycle) in both autotrophs and heterotrophs. In heterotrophs, it is the energy fixed up during photosynthesis, which feeds these biochemical reactions, but the carbon moiety can originate either from the sugars built up in photosynthesis or from the $\mathrm{CO}_{2}$ directly fixed by the heterotrophs.
}

2002; Staddon et al., 2003; Olsson and Johnson, 2005; Leake et al., 2006). Thereafter, within hours to days the carbon is either built into the hyphal structures, respired, or making its way through other members of the hypho- or rhizosphere (Jones et al., 2004; Leake et al., 2006; Kramer et al., 2012). Drigo et al. (2010) demonstrated fast movement of $\mathrm{C}$ from the plants to the AM hyphae and thereafter a gradual transfer of the carbon to Burkholderia and Pseudomonas, likely the hyphae-associative microbes. In contrast, no appreciable allocation of $\mathrm{C}$ was observed to Bacillus and Actinobacteria. In another experiment it was shown that, upon the presence of AM fungal hyphae in ${ }^{13} \mathrm{C}$-labeled organic patches, fatty acid biomarkers for a number of prokaryotic groups were less enriched in ${ }^{13} \mathrm{C}$ than those in patches not colonized by the AM fungi (Herman et al., 2012). This indicates that (at least some) of the prokaryotes derived their C preferentially from the AM fungi rather than from the plant litter. How is the $\mathrm{C}$ directed toward the hyphae-associated microbes is not completely known, but it has been hypothesized that trehalose released by the AM hyphae or other hyphal exudates may play a role (Bago et al., 1999; Drigo et al., 2010).

An alternative pathway of the $\mathrm{C}$ moving from plants to the hyphae-associated microbes is through the decay of dead AM hyphae or through grazing on living hyphae (Figure 2). These processes can be rather fast, especially given that the half-life of some of the terminal hyphae is just a few days (Staddon et al., 2003). However, cell walls of the hyphae are unlikely to be degraded fast, and, because the active cytoplasm is usually retracted to the backbone hyphae upon death of the terminal hyphal branches (Bago et al., 1998; Logi et al., 1998), there is not much fast food left for the degraders. On the other hand, specialized grazers on the hyphae can get access to the living cytoplasm, redistributing the hyphal cell content/carbon throughout the soil on short time scales (Fitter and Garbaye, 1994; Klironomos and Ursic, 1998).

Still another pathway for the plant $\mathrm{C}$ to get into the soil is through the root cell products (exudates) or dead root cells or biomass transferred to grazing/parasitic animals or microbes (Figure 2). These can also move through the soil and this movement can effectively mix a large soil volume. This mixing can be so intensive that it can effectively disable observation of spatially discrete processes such as localized transfer of $\mathrm{C}$ from the hyphae to associated microbes.

Under the condition that some hyphae-associated microbes get direct access to fungal C, e.g., in forms of hyphal exudates (Artursson and Jansson, 2003; Toljander et al., 2007) and, at the same time, they fulfill functions beneficial for the AM fungus or the associated plant, such co-existence could be classified as hypersymbiosis (Starr, 1975). However, to the best of our knowledge, unequivocal proof of hypersymbiosis still needs to be established in this case, especially because the identity of the different microbes could not yet be directly linked to their functions in situ.

\section{DYNAMICS OF THE ASSOCIATIONS UNDER FLUCTUATING ENVIRONMENTAL CONDITIONS}

Changing ecosystem-wide environmental conditions (e.g., temperature, humidity, atmospheric $\mathrm{CO}_{2}$ levels) will likely change a great number of ecosystem parameters including the size and composition of soil microbial communities, routes of $\mathrm{C}$ fluxes, rates 


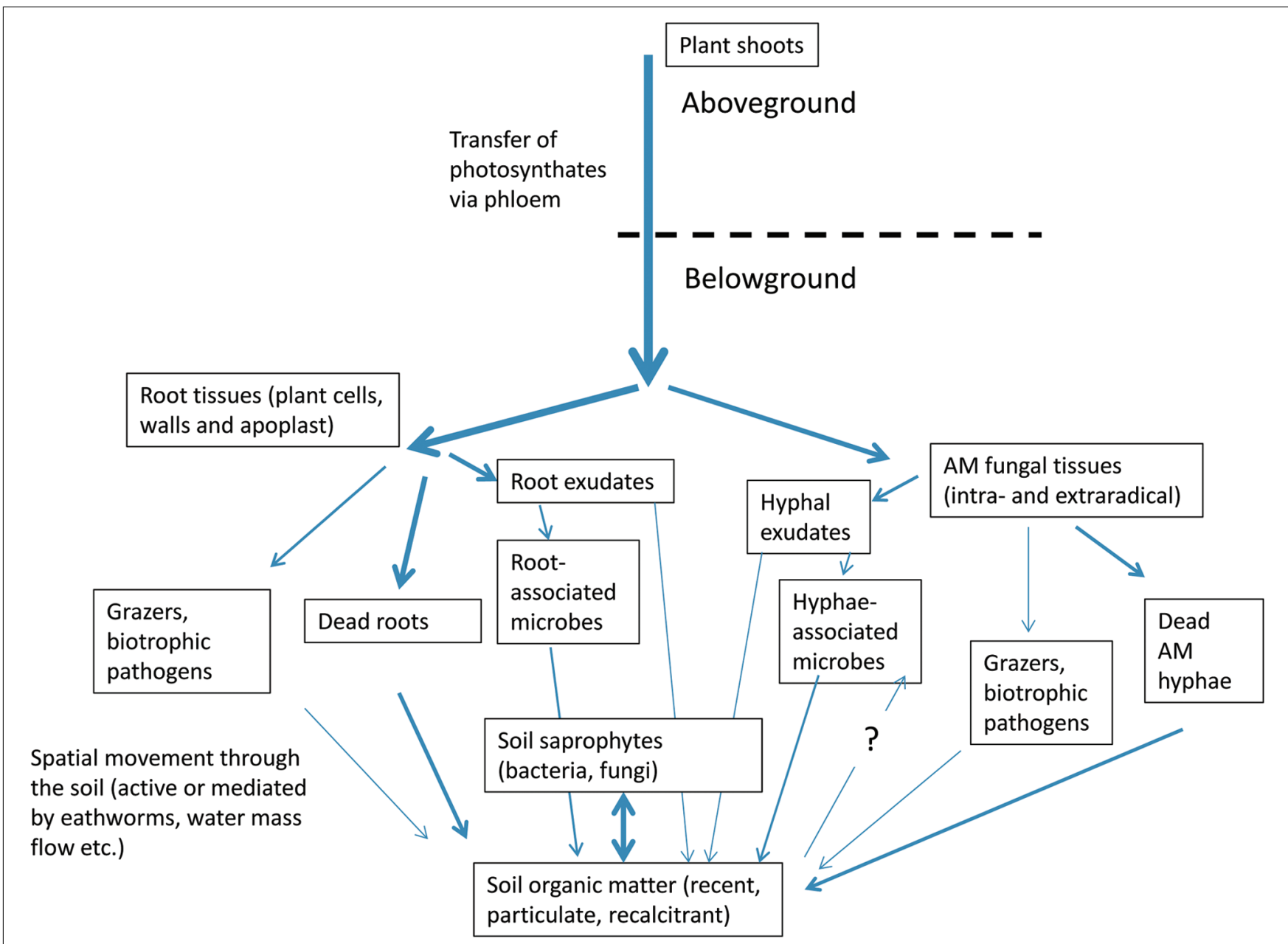

FIGURE 2 | Pathways of photosynthetically fixed carbon redistribution in the belowground compartment of the plant-fungal-soil system. Thickness of lines represents approximate volume/rate of fluxes. Respiration losses associated with every step and inputs through aboveground litter are not shown here.

and pathways of organic nutrient recycling, and ecosystem productivity (St Clair and Lynch, 2010; Cheng et al., 2012; Gutknecht et al., 2012; Zavalloni et al., 2012; Drigo et al., 2013). In soil, environmental conditions can also change dramatically on a small spatial scale, for example through deposition of organic materials such as plant litter or dung, local disturbance through burrowing animal activities and the like (Freymann et al., 2010; Stromberger et al., 2012).

Response of AM fungi to fluctuation of soil conditions and also how the benefits of the host plants derived from the mycorrhizal symbiosis vary upon changing the environmental conditions are the subject of research in a number of ongoing studies (Drigo et al., 2010; Hawkes et al., 2011; Gavito and Azcon-Aguilar, 2012; Gutknecht et al., 2012; Drigo et al., 2013). However, how stable is the association of AM fungi with their hyphae-associated microbes when exposed to different or changing environmental conditions, whether the composition and/or function of the associative microbes shifts depending on the quality of organic materials in the hyphal vicinity, has not yet been explicitly addressed.

\section{FURTHER RESEARCH NEEDS}

Obviously, association of AM hyphae with specific microbes is potentially explaining many unexpected, contradictory, and poorly replicable observations in the past. One of the most fascinating quests of mycorrhizal ecology is now to determine if these microbes are metabolically associated with AM fungal hyphae (i.e., deriving their C exclusively or mainly from the hyphae) or whether they derive their energy mainly from mineralization of soil organic matter. The first scenario would qualify these prokaryotes as hypersymbionts, which would add further level of complexity in our understanding of symbiotic world, whereas the second scenario would advocate for a theory of facultative associations. So far it is not possible to unequivocally declare any of the microbes found in the AM fungal hyphosphere as hypersymbionts, although preliminary evidence suggests preferential $\mathrm{C}$ flow from the hyphae to certain rhizosphere bacteria (Drigo et al., 2010). At the same time, however, strong evidence is missing for any direct benefits of these very microbes to their fungal hosts.

A second very interesting story is how resistant is this association to the fluctuations of environmental conditions. Do the 
AM fungi recruit different microbial community on their hyphae depending on the specific soil conditions, or is the identity of the microbes rather stable, and just their function adapts, e.g., when submitted to different soil conditions such as organic patches? Is it thus beneficial to develop mechanisms to vertically transmit the associative microbes to next generations or is the community established always anew, after the spore germinates and/or the secondary mycelium develops?

There is currently a whole range of methods allowing unprecedented precision and high throughput data production (e.g., next generation sequencing and proteomic analyses). Using stable and radioactive isotopes allows quantification of fluxes of carbon and mineral nutrients, and even the organisms involved in some of the processes (i.e., stable isotope probing for tracing the pathways of $\mathrm{C}$ fluxing). However, these methods, regardless of their novelty and precision, need to be applied in smartly designed experiments, with proper controls and with sufficient number of replicates/gradient coverage. Thus proper design of the

\section{REFERENCES}

Allen, M. F. (2007). Mycorrhizal fungi: highways for water and nutrients in arid soils. Vadose Zone J. 6, 291-297.

Alonso, L. M., Kleiner, D., and Ortega, E. (2008). Spores of the mycorrhizal fungus Glomus mosseae host yeasts that solubilize phosphate and accumulate polyphosphates. Mycorrhiza 18, 197-204.

Artursson, V., and Jansson, J. K. (2003). Use of bromodeoxyuridine immunocapture to identify active bacteria associated with arbuscular mycorrhizal hyphae. Appl. Environ. Microbiol. 69, 6208-6215.

Augé, R. M. (2004). Arbuscular mycorrhizae and soil/plant water relations. Can. J. Soil Sci. 84, 373-381.

Bago, B., Azcon-Aguilar, C., Goulet, A., and Piché, Y. (1998). Branched absorbing structures (BAS): a feature of the extraradical mycelium of symbiotic arbuscular mycorrhizal fungi. New Phytol. 139, 375-388.

Bago, B., Pfeffer, P. E., Douds, D. D., Brouillette, J., Bécard, G., and Shachar-Hill, Y. (1999). Carbon metabolism in spores of the arbuscular mycorrhizal fungus Glomus intraradices as revealed by nuclear magnetic resonance spectroscopy. Plant Physiol. 121, 263-271.

Barto, E. K., Hilker, M., Muller, F., Mohney, B. K., Weidenhamer, J. D., and Rillig, M. C. (2011). The fungal fast lane: Common mycorrhizal networks extend bioactive zones of allelochemicals in soils. PLoS ONE 6:e27195. doi: 10.1371/journal.pone.0027195

Bending, G. D., and Read, D. J. (1997). Lignin and soluble phenolic degradation by ectomycorrhizal and ericoid mycorrhizal fungi. Mycol. Res. 101, 1348-1354.
Berbee, M. L., and Taylor, J. W. (2007). Rhynie chert: a window into a lost world of complex plant-fungus interactions. New Phytol. 174, 475-479.

Bidondo, L. F., Silvani, V., Colombo, R., Pergola, M., Bompadre, J., and Godeas, A. (2011). Pre-symbiotic and symbiotic interactions between Glomus intraradices and two Paenibacillus species isolated from AM propagules. In vitro and in vivo assays with soybean (AG043RG) as plant host. Soil Biol. Biochem. 43, 1866-1872.

Boby, V. U., Balakrishna, A. N., and Bagyaraj, D. J. (2008). Interaction between Glomus mosseae and soil yeasts on growth and nutrition of cowpea. Microbiol. Res. 163, 693-700.

Bolliger, A., Nalla, A., Magid, J., De Neergaard, A., Nalla, A. D., and BogHansen, T. C. (2008). Re-examining the glomalin-purity of glomalinrelated soil protein fractions through immunochemical, lectin-affinity and soil labelling experiments. Soil Biol. Biochem. 40, 887-893.

Bonfante, P., and Anca, I. A. (2009). Plants, mycorrhizal fungi, and bacteria: a network of interactions. Annu. Rev. Microbiol. 63, 363-383.

Botha, A. (2011). The importance and ecology of yeasts in soil. Soil Biol. Biochem. 43, 1-8. of mycorrhiza systems. Naturwissenschaften $87,467-475$.

Calderon, F. J., Schultz, D. J., and Paul, E. A. (2012). Carbon allocation, belowground transfers, and lipid turnover in a plant-microbial association. Soil Sci. Soc. Am. J. 76, 1614-1623.

Chefetz, B., Chen, Y., and Hadar, Y. (1998). Purification and characterization of laccase from Chaetomium
Cairney, J. W. G. (2000). Evolution

experiments addressing the open questions is fully as important as the proper use of the available analytical tools.

The studies of hyphae-associated microorganisms will have to take into account the variability and dynamic behavior of the soil as the environment for the life of microbial community. An interdisciplinary approach involving the viewpoints of soil chemistry, physics, population biology, mycology, and plant physiology will probably be unavoidable to receive reliable understanding of the role played by the inhabitants of AM hyphae surfaces.

\section{ACKNOWLEDGMENTS}

Jan Jansa was supported by the J.E. Purkyně Fellowship granted by the Academy of Sciences of the Czech Republic. The authors were also supported by Czech Science Foundation (P504121665), Ministry of Education, Youth and Sports (LK11224), and the long-term development program RVO 61388971. Constructive comments of two anonymous reviewers are gratefully acknowledged. We also thank K. Sigler for language editing.

thermophilium and its role in humification. Appl. Environ. Microbiol. 64, 3175-3179.

Cheng, L., Booker, F. L., Tu, C., Burkey, K. O., Zhou, L. S., Shew, H. D., et al. (2012). Arbuscular mycorrhizal fungi increase organic carbon decomposition under elevated CO2. Science 337 , 1084-1087.

Drew, E. A., Murray, R. S., Smith, S. E., and Jakobsen, I. (2003). Beyond the rhizosphere: growth and function of arbuscular mycorrhizal external hyphae in sands of varying pore sizes. Plant Soil 251, 105-114.

Drigo, B., Kowalchuk, G. A., Knapp, B. A., Pijl, A. S., Boschker, H. T. S., and Van Veen, J. A. (2013). Impacts of 3 years of elevated atmospheric $\mathrm{CO} 2$ on rhizosphere carbon flow and microbial community dynamics. Glob. Change Biol. 19, 621-636.

Drigo, B., Pijl, A. S., Duyts, H., Kielak, A., Gamper, H. A., Houtekamer, M. J., et al. (2010). Shifting carbon flow from roots into associated microbial communities in response to elevated atmospheric CO2. Proc. Natl. Acad. Sci. U.S.A. 107, 10938-10942.

Faeth, S. H., and Fagan, W. F. (2002). Fungal endophytes: common host plant symbionts but uncommon mutualists. Integr. Comp. Biol. 42, 360-368.

Fellbaum, C. R., Gachomo, E. W., Beesetty, Y., Choudhari, S., Strahan, G. D., Pfeffer, P. E., et al. (2012). Carbon availability triggers fungal nitrogen uptake and transport in arbuscular mycorrhizal symbiosis. Proc. Natl. Acad. Sci. U.S.A. 109, 2666-2671.

Feng, G., Song, Y. C., Li, X. L., and Christie, P. (2003). Contribution of arbuscular mycorrhizal fungi to utilization of organic sources of phosphorus by red clover in a calcareous soil. Appl. Soil Ecol. 22, 139-148.

Fitter, A. H., and Garbaye, J. (1994). Interactions between mycorrhizal fungi and other soil organisms. Plant Soil 159, 123-132.

Frey-Klett, P., Garbaye, J., and Tarkka, M. (2007). The mycorrhiza helper bacteria revisited. New Phytol. 176, 22-36.

Freymann, B. P., De Visser, S. N., and Olff, H. (2010). Spatial and temporal hotspots of termite-driven decomposition in the Serengeti. Ecography 33, 443-450.

Gadkar, V., and Rillig, M. C. (2006). The arbuscular mycorrhizal fungal protein glomalin is a putative homolog of heat shock protein 60. FEMS Microbiol. Lett. 263, 93-101.

Garbaye, J. (1994). Helper bacteria a new dimension to the mycorrhizal symbiosis. New Phytol. 128, 197-210. Gavito, M. E., and Azcon-Aguilar, C. (2012). Temperature stress in arbuscular mycorrhizal fungi: a test for adaptation to soil temperature in three isolates of Funneliformis mosseae from different climates. Agric. Food Sci. 21, 2-11.

Ghignone, S., Salvioli, A., Anca, I., Lumini, E., Ortu, G., Petiti, L., et al. (2012). The genome of the obligate endobacterium of an AM fungus reveals an interphylum network of nutritional interactions. ISME J. 6, 136-145.

Gonzalez-Chavez, M. D. A., Newsam, R., Linderman, R., Dodd, J., and Valdez-Carrasco, J. M. (2008). Bacteria associated with the extraradical mycelium of an arbuscular mycorrhizal fungus in an $\mathrm{As} / \mathrm{Cu}$ polluted soil. Agrociencia 42, 1-10. 
Gryndler, M., and Hršelová, H. (1998). Effect of flavonoids on in-vitro proliferation of hyphae of Glomus fistulosum. Biol. Plant. 41, 303-306.

Gryndler, M., Hršelová, H., Chvátalová, I., and Jansa, J. (1998). The effect of selected plant hormones on in vitro proliferation of hyphae of Glomus fistulosum. Biol. Plant. 41, 255-263.

Gryndler, M., Soukupová, L., Hršelová, H., Gryndlerová, H., Borovička, J., Streiblová, E., et al. (2013). A quest for indigenous truffle-helper prokaryotes. Environ. Microbiol. Rep. 5, 346-352.

Gutknecht, J. L. M., Field, C. B., and Balser, T. C. (2012). Microbial communities and their responses to simulated global change fluctuate greatly over multiple years. Glob. Change Biol. 18, 2256-2269.

Hawkes, C. V., Kivlin, S. N., Rocca, J. D., Huguet, V., Thomsen, M. A., and Suttle, K. B. (2011). Fungal community responses to precipitation. Glob. Change Biol. 17, 1637-1645.

Herman, D. J., Firestone, M. K., Nuccio, E., and Hodge, A. (2012). Interactions between an arbuscular mycorrhizal fungus and a soil microbial community mediating litter decomposition. FEMS Microbiol. Ecol. 80, 236-247.

Hodge, A. (2001). Arbuscular mycorrhizal fungi influence decomposition of, but not plant nutrient capture from, glycine patches in soil. New Phytol. 151, 725-734.

Hodge, A. (2003). Plant nitrogen capture from organic matter as affected by spatial dispersion, interspecific competition and mycorrhizal colonization. New Phytol. 157, 303-314.

Hodge, A., Campbell, C. D., and Fitter, A. H. (2001). An arbuscular mycorrhizal fungus accelerates decomposition and acquires nitrogen directly from organic material. Nature 413, 297-299.

Hodge, A., Robinson, D., and Fitter, A. H. (2000). An arbuscular mycorrhizal inoculum enhances root proliferation in, but not nitrogen capture from, nutrient-rich patches in soil. New Phytol. 145, 575-584.

Hoffman, M. T., and Arnold, A. E. (2010). Diverse bacteria inhabit living hyphae of phylogenetically diverse fungal endophytes. Appl. Environ. Microbiol. 76, 4063-4075.

Hyde, K. D., and Soytong, K. (2008). The fungal endophyte dilemma. Fungal Divers. 33, 163-173.

Izumi, H., Elfstrand, M., and Fransson, P. (2013). Suillus mycelia under elevated atmospheric $\mathrm{CO} 2$ support increased bacterial communities and scarce nifH gene activity in contrast to Hebeloma mycelia. Mycorrhiza 23, 155-165.

Jakobsen, I. (1983). Vesiculararbuscular mycorrhiza in field-grown crops.2. Effect of Inoculation on growth and nutrient uptake in barley at 2 phosphorus levels in fumigated soil. New Phytol. 94, 595-604.

Jakobsen, I., Abbott, L. K., and Robson, A. D. (1992). External hyphae of vesicular arbuscular mycorrhizal fungi associated with Trifolium subterraneum L. 2. Hyphal transport of $32 \mathrm{P}$ over defined distances. New Phytol. 120, 509-516.

Jakobsen, I., and Rosendahl, L. (1990). Carbon flow into soil and external hyphae from roots of mycorrhizal cucumber plants. New Phytol. 115, 77-83.

Janos, D. P., Garamszegi, S., and Beltran, B. (2008). Glomalin extraction and measurement. Soil Biol. Biochem. 40, 728-739.

Jansa, J., Finlay, R. D., Wallander, H., Smith, F. A., and Smith, S. E. (2011) "Role of mycorrhizal symbioses in phosphorus cycling," in Phosphorus in Action, eds E. K. Bünemann, A. Oberson, and E. Frossard. (Heidelberg: Springer), 137-168.

Jansa, J., and Gryndler, M. (2010). "Biotic environment of the arbuscular mycorrhizal fungi in soil," in Arbuscular Mycorrhizas: Physiology and Function, eds H. Koltai and Y. Kapulnik. (Heidelberg: Springer) 209-236.

Jansa, J., Mozafar, A., and Frossard E. (2003). Long-distance transport of $\mathrm{P}$ and $\mathrm{Zn}$ through the hyphae of an arbuscular mycorrhizal fungus in symbiosis with maize. Agronomie 23, 481-488

Jeon, J. R., Baldrian, P., Murugesan, K., and Chang, Y. S. (2012). Laccase-catalysed oxidations of naturally occurring phenols: from in vivo biosynthetic pathways to green synthetic applications. Microb. Biotechnol. 5, 318-332.

Johnson, D., Leake, J. R., Ostle, N., Ineson, P., and Read, D. J. (2002). In situ $13 \mathrm{CO} 2$ pulse-labelling of upland grassland demonstrates a rapid pathway of carbon flux from arbuscular mycorrhizal mycelia to the soil. New Phytol. 153, 327-334.

Johnson, N. C., and Graham, J. H. (2013). The continuum concept remains a useful framework for studying mycorrhizal functioning. Plant Soil 363, 411-419.

Johnson, N. C., Graham, J. H., and Smith, F. A. (1997). Functioning of mycorrhizal associations along the mutualism-parasitism continuum. New Phytol. 135, 575-586.
Joner, E. J., and Jakobsen, I. (1995). Uptake of 32P from labeled organic matter by mycorrhizal and nonmycorrhizal subterranean clover (Tri folium subterraneum L). Plant Soil 172, 221-227.

Joner, E. J., Van Aarle, I. M., and Vosátka, M. (2000). Phosphatase activity of extra-radical arbuscular mycorrhizal hyphae: a review. Plant Soil 226, 199-210.

Jones, D. L., Hodge, A., and Kuzyakov, Y. (2004). Plant and mycorrhizal regulation of rhizodeposition. New Phytol. 163, 459-480.

Kariman, K., Barker, S. J., Finnegan, P. M., and Tibbett, M. (2012). Dual mycorrhizal associations of jarrah (Eucalyptus marginata) in a nursepot system. Aust. J. Bot. 60, 661-668.

Kataoka, R., Taniguchi, T., Ooshima, H., and Futai, K. (2008). Comparison of the bacterial communities established on the mycorrhizae formed on Pinus thunbergii root tips by eight species of fungi. Plant Soil 304, 267-275.

Klironomos, J. N., and Ursic, M. (1998). Density-dependent grazing on the extraradical hyphal network of the arbuscular mycorrhizal fungus, Glomus intraradices, by the collembolan, Folsomia candida. Biol. Fertil. Soils 26 250-253.

Koide, R. T., and Kabir, Z. (2000). Extraradical hyphae of the mycorrhizal fungus Glomus intraradices can hydrolyse organic phosphate. New Phytol. 148, 511-517.

Kramer, S., Marhan, S., Ruess, L., Armbruster, W., Butenschoen, O. Haslwimmer, H., et al. (2012). Carbon flow into microbial and fungal biomass as a basis for the belowground food web of agroecosystems. Pedobiologia 55, 111-119.

Laheurte, F., Leyval, C., and Berthelin, J. (1990). Root exudates of maize, pine and beech seedlings influenced by mycorrhizal and bacterial inoculation. Symbiosis 9, 111-116.

Leake, J. R., Ostle, N. J., RangelCastro, J. I., and Johnson, D. (2006). Carbon fluxes from plants through soil organisms determined by field $13 \mathrm{CO} 2$ pulse-labelling in an upland grassland. Appl. Soil Ecol. 33, 152-175.

Leigh, J., Fitter, A. H., and Hodge, A. (2011). Growth and symbiotic effectiveness of an arbuscular mycorrhizal fungus in organic matter in competition with soil bacteria. FEMS Microbiol. Ecol. 76, 428-438.

Lendenmann, M., Thonar, C., Barnard, R. L., Salmon, Y., Werner, R. A., Frossard, E., et al. (2011). Symbiont identity matters: carbon and phosphorus fluxes between Medicago truncatula and different arbuscular mycorrhizal fungi. Mycorrhiza 21, 689-702.

Li, X. L., Marschner, H., and George, E. (1991). Acquisition of phosphorus and copper by VA mycorrhizal hyphae and root-to-shoot transport in white clover. Plant Soil 136, 49-57.

Logi, C., Sbrana, C., and Giovannetti, M. (1998). Cellular events involved in survival of individual arbuscular mycorrhizal symbionts growing in the absence of the host. Appl. Environ. Microbiol. 64, 3473-3479.

Mäder, P., Vierheilig, H., StreitwolfEngel, R., Boller, T., Frey, B., Christie, P., et al. (2000). Transport of $15 \mathrm{~N}$ from a soil compartment separated by a polytetrafluoroethylene membrane to plant roots via the hyphae of arbuscular mycorrhizal fungi. New Phytol. 146, 155-161.

Martin, F., Aerts, A., Ahren, D., Brun, A., Danchin, E. G. J., Duchaussoy, F., et al. (2008). The genome of Laccaria bicolor provides insights into mycorrhizal symbiosis. Nature 452, 88-U87.

Millner, P. D., and Wright, S. F. (2002). Tools for support of ecological research on arbuscular mycorrhizal fungi. Symbiosis 33, 101-123.

Miransari, M. (2011). Arbuscular mycorrhizal fungi and nitrogen uptake. Arch. Microbiol. 193, 77-81.

Mosse, B. (1957). Growth and chemical composition of mycorrhizal and non-mycorrhizal apples. Nature 179, 923-924.

Neuhauser, C., and Fargione, J. E. (2004). A mutualisim-parasitism continuum model and its application to plant-mycorrhizae interactions. Ecol. Modell. 177, 337-352.

Olsson, P. A., and Johnson, N. C. (2005). Tracking carbon from the atmosphere to the rhizosphere. Ecol. Lett. 8, 1264-1270.

Paul, E. A., and Kucey, R. M. N. (1981). Carbon flow in plant microbial associations. Science 213, 473-474.

Paul, L. R., Chapman, B. K., and Chanway, C. P. (2007). Nitrogen fixation associated with Suillus tomentosus tuberculate ectomycorrhizae on Pinus contorta var. latifolia. Ann. Bot. 99, 1101-1109.

Piccolo, A., Cozzolino, A., Conte, P., and Spaccini, R. (2000). Polymerization of humic substances by an enzymecatalyzed oxidative coupling. Naturwissenschaften 87, 391-394.

Read, D. J., Duckett, J. G., Francis, R., Ligrone, R., and Russell, A. (2000). Symbiotic fungal associations in 'lower' land plants. Philos. Trans. $R$. Soc. Lond. B Biol. Sci. 355, 815-830. 
Read, D. J., Leake, J. R., and Perez-Moreno, J. (2004). Mycorrhizal fungi as drivers of ecosystem processes in heathland and boreal forest biomes. Can. J. Bot. 82, 1243-1263.

Redecker, D., Kodner, R., and Graham, L. E. (2000). Glomalean fungi from the Ordovician. Science 289, 1920-1921.

Remy, W., Taylor, T. N., Hass, H., and Kerp, H. (1994). 4-Hundred million year old vesicular arbuscular mycorrhizae. Proc. Natl. Acad. Sci. U.S.A. 91, 11841-11843.

Rillig, M. C. (2004). Arbuscular mycorrhizae, glomalin, and soil aggregation. Can. J. Soil Sci. 84, 355-363.

Seipke, R. F., Kaltenpoth, M., and Hutchings, M. I. (2012). Streptomyces as symbionts: an emerging and widespread theme? FEMS Microbiol. Rev. 36, 862-876.

Scherer, H. W., and Frost, M. (2004). Depletion of non-exchangeable $\mathrm{NH} 4+$ at the root-soil and hyphaesoil interface of VA mycorrhizal maize (Zea mays) and parsley (Petroselinum sativum). J. Plant Nutr. Soil Sci. 167, 713-719.

Scheublin, T. R., Sanders, I. R., Keel, C., and Van Der Meer, J. R. (2010). Characterisation of microbial communities colonising the hyphal surfaces of arbuscular mycorrhizal fungi. ISME J. 4, 752-763.

Schnepf, A., and Roose, T. (2006). Modelling the contribution of arbuscular mycorrhizal fungi to plant phosphate uptake. New Phytol. 171, 669-682.

Schüßler, A., Schwarzott, D., and Walker, C. (2001). A new fungal phylum, the Glomeromycota: phylogeny and evolution. Mycol. Res. 105, 1413-1421.

Schweiger, P., and Jakobsen, I. (2000). Laboratory and field methods for measurement of hyphal uptake of nutrients in soil. Plant Soil 226, 237-244.
Simon, L., Bousquet, J., Levesque, R. C., and Lalonde, M. (1993). Origin and diversification of endomycorrhizal fungi and coincidence with vascular land plants. Nature 363, 67-69.

Sinsabaugh, R. L. (2010). Phenol oxidase, peroxidase and organic matter dynamics of soil. Soil Biol. Biochem. 42, 391-404.

Smith, S. E., and Read, D. J. (2008). Mycorrhizal Symbiosis. Amsterdam: Academic Publishers.

Sousa, C. D., Menezes, R. S. C., Sampaio, E. V. D. B., and Lima, F D. (2012). Glomalin: characteristics, production, limitations and contribution to soils. Semina: Ciências Agrárias 33, 3033-3044.

St Clair, S. B., and Lynch, J. P. (2010). The opening of Pandora's Box: climate change impacts on soil fertility and crop nutrition in developing countries. Plant Soil 335, 101-115.

Staddon, P. L., Ramsey, C. B., Ostle, N., Ineson, P., and Fitter, A. H. (2003). Rapid turnover of hyphae of mycorrhizal fungi determined by AMS microanalysis of 14C. Science 300 1138-1140.

Starr, M. P. (1975). "A generalized scheme for classifying organismic associations," in Symposia of the Society for Experimental Biology, No. 29: Symbiosis, eds D. H. Jennings and D. L. Lee. (Cambridge: Cambridge University Press), 1-20.

Stromberger, M. E., Keith, A. M., and Schmidt, O. (2012). Distinct microbial and faunal communities and translocated carbon in Lumbricus terrestris drilospheres. Soil Biol. Biochem. 46, 155-162.

Talbot, J. M., Allison, S. D., and Treseder, K. K. (2008). Decomposers in disguise: mycorrhizal fungi as regulators of soil C dynamics in ecosystems under global change. Funct. Ecol. 22, 955-963.
Tanaka, Y., and Yano, K. (2005). Nitrogen delivery to maize via mycorrhizal hyphae depends on the form of N supplied. Plant Cell Environ. 28, 1247-1254.

Tarafdar, J. C., and Marschner, H. (1994). Efficiency of VAMhyphae in utilization of organic phosphorus by wheat plants. Soil Sci. Plant Nutr. 40, 593-600.

Taylor, T. N., and Krings, M. (2005) Fossil microorganisms and land plants: associations and interactions. Symbiosis 40, 119-135.

Thonar, C., Schnepf, A., Frossard, E., Roose, T., and Jansa, J. (2011). Traits related to differences in function among three arbuscular mycorrhizal fungi. Plant Soil 339, 231-245.

Timonen, S., and Hurek, T. (2006). Characterization of culturable bacterial populations associating with Pinus sylvestris-Suillus bovinus mycorrhizospheres. Can. J. Microbiol. 52, 769-778.

Toljander, J. F., Artursson, V., Paul, L. R., Jansson, J. K., and Finlay, R. D. (2006). Attachment of different soil bacteria to arbuscular mycorrhizal fungal extraradical hyphae is determined by hyphal vitality and fungal species. FEMS Microbiol. Lett. 254, 34-40.

Toljander, J. F., Lindahl, B. D., Paul, L. R., Elfstrand, M., and Finlay, R. D. (2007). Influence of arbuscular mycorrhizal mycelial exudates on soil bacterial growth and community structure. FEMS Microbiol. Ecol. 61 295-304.

Treseder, K. K., and Turner, K. M. (2007). Glomalin in ecosystems. Soil Sci. Soc. Am. J. 71, 1257-1266.

Wang, B., and Qiu, Y. L. (2006). Phylogenetic distribution and evolution of mycorrhizas in land plants. Mycorrhiza 16, 299-363.

Whiffen, L. K., Midgley, D. J., and Mcgee, P. A. (2007). Polyphenolic compounds interfere with quantification of protein in soil extracts using the Bradford method. Soil Biol. Biochem. 39, 691-694.

Wright, S. F., Rillig, M. C., and Nichols, K. A. (2000). Glomalin: a soil protein important in carbon sequestration. Abstr. Pap. Am. Chem. Soc. 220, U396-U396.

Zavalloni, C., Vicca, S., Buscher, M., De La Providencia, I. E., De Boulois, H. D., Declerck, S., et al. (2012). Exposure to warming and $\mathrm{CO} 2$ enrichment promotes greater above-ground biomass, nitrogen, phosphorus and arbuscular mycorrhizal colonization in newly established grasslands. Plant Soil 359, 121-136.

Zavarzina, A. G. (2010). Formation of humin and humic acids by surface precursor polymerization: implications to primitive and well-developed soils. Geochim. Cosmochim. Acta 74, A1196.

Conflict of Interest Statement: The authors declare that the research was conducted in the absence of any commercial or financial relationships that could be construed as a potential conflict of interest.

Received: 13 March 2013; accepted: 22 April 2013; published online: 16 May 2013.

Citation: Jansa J, Bukovská P, Gryndler M (2013) Mycorrhizal hyphae as ecological niche for highly specialized hypersymbionts - or just soil free-riders? Front. Plant Sci. 4:134. doi: 10.3389/ fpls.2013.00134

This article was submitted to Frontiers in Plant-Microbe Interaction, a specialty of Frontiers in Plant Science.

Copyright $\odot 2013$ Jansa, Bukovská, Gryndler. This is an open-access article distributed under the terms of the Creative Commons Attribution License, which permits use, distribution and reproduction in other forums, provided the original authors and source are credited and subject to any copyright notices concerning any third-party graphics etc. 